\title{
RABBIT PRODUCTION AS AGRO- ENTREPRENEUR FOR STUDENTS IN TERTIARY INSTITUTION: A STUDY OF FEDERAL COLLEGE OF AGRICULTURE AKURE
}

\author{
Okpakpor, U. E. ${ }^{\mathrm{a}}$ and Olorunsogbon, B.F. ${ }^{\mathrm{b}}$ \\ ${ }^{a}$ Department of Animal Production and Health Technology, Federal College of Agriculture, \\ Akure. Ondo State, Nigeria. \\ ${ }^{b}$ Department of Agricultural Technology. The Federal Polytechnic, Ilaro, Ogun State, Nigeria. \\ Corresponding author: bernard.olorunsogbon@federalpolyilaro.edu.ng \\ Telephone: +2348034699991
}

\section{ABSTRACT}

This study was designed to gather relevant information on the state of rabbit production among students within the campus with the aid of understanding their challenges, reasons for undertaking such ventures on campus, how they are able to combine rearing of rabbits with their studies. Students involved in rabbit farming were organized into groups. Using well-structured questionnaires and resource interview section information on effect of rabbit farming on students' academic performance, number of stock kept, reason they involved in the venture and challenges faced were collected. The result obtained in this study, it is observed that $90 \%$ of the students involved in rabbit farming on campus are male while only $10 \%$ are female. Seventy percent (70\%) of the respondents reported that rearing rabbits on campus has no effect on their academic performances while 30\% reported that it does. From the report on the production, $75 \%$ of the respondents went into the rabbit farming to make some extra money for themselves while only $2 \%$ are involved in it as a result of their student project. It can be concluded that the increase in number of rabbit farmers on the campus is mainly because the students want extra source of income.

Key words: rabbit production, campus, students, venture.

\subsection{Introduction}

The numerous attempts aimed at solving low protein intake and poverty alleviation by Nigerian government still remains a mirage (Nworgu and Hammed, 2009). To meet the increasing demand for animal protein, emphasis needs to be given to non-conventional sources such as easily managed rabbits as against the conventional sources such as cattle, sheep, goat, pig and poultry that would require more capital, space and time (Yusuf et. al., 2009). Domestic rabbits (Oryctolagus $\underline{\text { cuniculus })}$ are everywhere providing protein for food, research models and companionship among others. These qualities confer on rabbits a potential to bridge the shortage 
of animal protein in developing countries, where grain can only be justified for human use (Iribeck, 2001).

Over the years the number of students rearing rabbit within the College of Agriculture Akure has kept on increasing but not much is known about the cause of such increase or why more students go into rabbit rearing within the college but encouraging such students in the venture may help the college address one of her mission which is to encourage and empower her students with the right skills through entrepreneurial and vocational studies.

This study was designed to gather relevant information on the state of rabbit production among students within the campus with the aid of understanding their challenges, reasons for undertaking such ventures on campus, how they are able to combine rearing of rabbits with their studies and if they wish to continue with the venture after their studies.

\subsection{Materials and Methods}

This study was carried out at the Federal College of Agriculture, Akure, west campus where student rearing rabbits are concentrated. Students involved in rabbit farming were organized into a group and several meetings were held with them to create awareness for the need of the study. All the students involved in rabbit production within the college showed interest to participate in the study. Using well-structured fifty (50) questionnaires were given out and resource interview section information on effect of rabbit farming on students' academic performance, number of stock kept, reason they involved in the venture and challenges faced were collected. All data generated from the questionnaires was analyzed descriptively using SPSS version 16 


\subsection{RESULT AND DISCUSSION}

Table 1: EFFECT OF RABBIT REARING ON ACADEMIC PERFORMANCE OF FEDERAL COLLEGE OF AGRICULTURE (FCA) STUDENTS, AKURE.

\begin{tabular}{|c|c|c|}
\hline Parameters & Frequency & Percentage $(\%)$ \\
\hline \multicolumn{3}{|l|}{ SEX } \\
\hline Male & 18 & 90 \\
\hline Female & 2 & 10 \\
\hline \multicolumn{3}{|l|}{ LEVEL } \\
\hline ND 1 & 5 & 25 \\
\hline ND 2 & 2 & 10 \\
\hline HND 1 & 3 & 15 \\
\hline HND 2 & 10 & 50 \\
\hline \multicolumn{3}{|l|}{ NUMBER OF SEMESTER USED IN REARING RABBIT } \\
\hline One semester & 1 & 5 \\
\hline Two semester & 10 & 50 \\
\hline Three semester & 7 & 35 \\
\hline Four semester & 2 & 10 \\
\hline \multicolumn{3}{|l|}{ DOES RABBIT REARING HAVE EFFECT ON YOUR } \\
\hline \multicolumn{3}{|l|}{ ACADEMIC PERFORMANCE } \\
\hline YES & 6 & 30 \\
\hline NO & 14 & 70 \\
\hline \multicolumn{3}{|l|}{ EFFECTS MENTIONED } \\
\hline No response & 14 & 70 \\
\hline It takes my time of reading & 5 & 25 \\
\hline The money to feed myself sometimes I use it in feeding rabbit & 1 & 5 \\
\hline \multicolumn{3}{|l|}{ DO YOU HAVE MENTOR IN RABBIT REARING } \\
\hline YES & 17 & 85 \\
\hline NO & 3 & 15 \\
\hline \multicolumn{3}{|l|}{ WHO ARE THE MENTORS } \\
\hline No response & 4 & 20 \\
\hline Other students & 2 & 10 \\
\hline Past students & 12 & 60 \\
\hline Others & 2 & 10 \\
\hline \multicolumn{3}{|l|}{ WILL YOU CONTINUE WITH THE VENTURE AFTER } \\
\hline \multicolumn{3}{|l|}{ GRADUATION } \\
\hline No response & 1 & 5 \\
\hline Yes & 19 & 95 \\
\hline No & 0 & 0 \\
\hline \multicolumn{3}{|l|}{ DO YOU HAVE ANY COMPLAIN BY OTHER } \\
\hline \multicolumn{3}{|l|}{ STUDENTS ABOUT YOU REARING RABBIT IN THE } \\
\hline \multicolumn{3}{|l|}{ SURROUNDING } \\
\hline No response & 1 & 5 \\
\hline Yes & 2 & 10 \\
\hline No & 17 & 85 \\
\hline
\end{tabular}


From the result obtained in this study, it is observed that $90 \%$ of the students involved in rabbit farming on campus are male while only $10 \%$ are female. These could be likened to the fact that most male students want extra source of income to support what they get from home. Seventy percent $(70 \%)$ of the respondents reported that rearing rabbits on campus has no effect on their academic performances while 30\% reported that it does. Oseni, et.al., (2008) had reported that rabbit farming is a venture which is not time consuming but $25 \%$ of the students reported that the venture takes up some of their study time, these could be as a result of poor time management on the part of the students.

Most of the students (85\%) involved in rabbit farming in Federal College of Agriculture (FCA), Akure had mentors who are mostly past students (60\%). These past students most have done their project using rabbits and later decided to keep the animals and make money from it.

From the report on the production focus, $75 \%$ of the respondents went into the rabbit farming to make some extra money for themselves while only $2 \%$ are involved in it as a result of their student project. This buttress the fact that rabbit farming could be a source of extra income (Shaeffer and Harper, 2008) even for students. The stock size reported in this study is between 0 - 10, majority of the respondent (70\%) have a stock 1-4 animals while only $10 \%$ has about 10 animals. This is an indication that the enterprise is a small scale venture and this could make it being easy for them to manage. Rabbit farming is often established as a small scale venture which makes management easy (Cheeke, 2005).

The respondents in this study reported various forms of challenges they face while having the rabbit farms on campus and some of the challenge reported includes. Ant invasion which often kills their animal, lack of market to sell off their stock, theft of animal by other students, outbreak of diseases and sudden death of animal among others. This challenges reported in this work are similar to these report by (Ozor and Madukwe, 2005) in his study on challenges of rabbit farming. Ninety five percent $(95 \%)$ of the respondents reported that they will continue with the venture even after graduation, these could be an indicator that while on campus the venture has paid them off and so continuity is an option. $75 \%$ of the respondents in this report uses wooden cage and $10 \%$ uses other houses while $15 \%$ of them uses bamboo cage. Most of the cages used were constructed by the students themselves, hence there is reduction in cost of production. The type of pen used and the management of the animals could bring about outbreak 
of diseases on the farm as we observed during administration of the questionnaire since most of the surrounding of the rabbit farm were looking unkept. Only $10 \%$ of the respondents report that their colleagues in the hostel complained about them keeping rabbit in the hostel.

\section{CONCLUSION}

From the result obtained in this study, it can be concluded that the increase in number of rabbit farmers on the campus of Federal College of Agriculture (FECA), Akure is mainly because the students want extra source of income other than what they get from home and since rabbit rearing could fetch them such income without affecting their studies, they get involved in it other than cyber theft. Also the students involved in the venture can be self-employed after their graduation until they get a better job since (Oseni et.al., 2008) reported that rabbit farming is a venture that will allow one take up other job without affecting it.

\section{RECOMMENDATION}

It is therefore recommend that, the students involved in the venture should try and

i. use better housing facility and keep the surrounding of the pen clean to help reduce or avoid death of animal.

ii. approach the management of the college point of sales to help in sales of their product and also awareness should be done among other students on the importance of rabbit meat to the health of human hence promoting its consumption.

\section{REFERENCES}

Cheeke, P.R. (2005) Livestock feeds and feeding (3rd ed.), Pearson Prentice Hall, Upper Saddle River, New Jersey (2005)

Iribeck, N. A. (2001). How to feed the rabbit (Oryctolagus cuniculus) gastro-intestinal tract. Journal animal science 79 (suppl): 343-346.

Nworgu, F.C. and Hammed, M.O. (2009). Performance of rabbits fed Altermantherna bettzikiana supplements. Proceedings of the 34th Annual Conference of Nigeria Society for Animal Production on 15th - 18th March, at Uyo. pp 644 - 646.

Oseni, S.O., Ajayi, B.A., Komolafe, S.O., Siyanbola, D., Ishola, M. and Madamidola, G. (2008). Smallholder rabbit production in southwestern Nigeria: current status, emerging issues and ways forward. 9th World Rabbit Congress, Verona, Italy. Pp 1597-1601.

Ozor, N. and Madukwe, M. C. (2005). Obstacles to the adoption of improved rabbit technologies by small-scale farmers in Nsukka Local Government Area of Enugu State. Journal of Agriculture, Food, Environment and Extension, 4(1): 70-73.

Shaeffer, R. and Harper, J. K. (2008). Rabbit production. Agricultural Alternatives. The Pennsylvania State University. 
Yusuf, A. M., Garba, M. H., Olafadeham, O. A. and Okafor, C. I. (2009). Evaluation of the feeding potentials of Vitellaria paradoxum, Nauclea latifolia and Terminalia macroptera foliage as supplements to concentrate feed for weaner rabbits. Proceedings of the $34^{\text {th }}$ Annual Conference of Nigerian Society for Animal Production (NSAP), 15-18th March, 2009, Uyo: 306 - 308. 